\title{
THE ANALYSIS OF INDIFERENCE AND THE PRICE ELASTICITY OF DEMAND BETWEEN DIFFERENT CATEGORIES OF AGRICULTURAL PRODUCTS
}

\author{
Predrag Vukadinovićl, Aleksandar Damnjanović2 , Jelena Krstić-Ranđic ${ }^{3}$
}

\begin{abstract}
In this paper, the analysis of the price elasticity of demand of four different categories of agricultural products in the Republic of Serbia was described. Differentiating the price and demand of these products by sales points, and using the least squares approximation method, the elasticity for all different agricultural categories was expressed in the functional form. According to this, the coefficients of elasticity of the price and demand were computed and between different agricultural categories were analyzed. The results we obtained show that the market of agricultural products in Serbia is mostly inelastic because the coefficients of inelasticity and indifference of demand to change of prices, are dominant. The influence of factors on the elasticity of demand that are not of price character, proved to be very pronounced. The relationship of the two segments of agricultural market (markets and shops) was also analysed and it was demonstrated that these two segments have a slight correlation.
\end{abstract}

Key words: price elasticity of demand, demand, price, demand quantity, indifference.

JEL: Q11, Q13, Q14, Q18

\section{Introduction}

It is widely accepted in the literature that the elasticity of demand expresses the relationship of percentage change in the quantity demanded of a product and percentage change in price (price elasticity of demand) or percentage changes of income of consumers (income elasticity). It is measured by the coefficient of elasticity which indicates the level of responsiveness of the quantity demanded of a product in relation to changes in the price of the goods or income of

1 Predrag Vukadinović Ph.D., Associate Professor, Singidunum University, Danijelova Street no. 32, 11000 Belgrade, Serbia, Phone: +381 11309 3741, E-mail: pvukadinovic@singidunum.ac.rs.

2 Corresponding author Aleksandar Damnjanović Ph.D., Associate Professor, Faculty for Economics „Dositej“'Belgrade „Dositej“, Nikole Pašića Square no. 7, 11000 Belgrade, Serbia, Phone: +381 64 0028 388, E-mail: adm.tfc@gmail.com.

3 Jelena Krstić Ranđić Ph.D., Assistant Professor, Higher Business School Leskovac, Vlade Jovanovica Street no. 8, 16000 Leskovac, Serbia, Phone: +381 6116424 75, E-mail: krstic.jelena@vpsle.edu.rs.

EP 2017 (64) 2 (671-685) 
the consumers. The price elasticity of demand is an important economic instrument without which it is not possible to make any significant business decisions regarding markets, market performance and market activities, bearing in mind increasingly fierce market competition. According to (Anderson et al., 1997), in order to predict consumer behaviour, economists use well-defined techniques for assessing the sensitivity of consumers to changes in price. The main generator of competition is certainly the mechanism of setting the market prices, established on the basis of economic law - the law of supply and demand (Božinović, Stojanović, 2011). The trend of price volatility of agricultural products shows growth in the period 1987-1993 and 1994-2005, while in the period 2006-2014 the trend of price volatility shows a decline, although the price volatility of certain agricultural products in this period also shows growth, especially for international agricultural products (Guerrero et al., 2016). Food prices doubled in real terms from 2005 to mid-2008 (Gilbert, 2008). This dramatic change in world food prices, is largely the result of speculative activities on the world commodity markets that were enabled by the measures of financial deregulation in the United States of America and elsewhere (Ghosh, 2010). Price volatility is affected by numerous factors. One of them is the farm size, as well as the adoption of certain changes that affect the productivity and thus the prices. Agriculture is an essential component of the European economy and society (Nazzaro and Marotta, 2016). The example of analysis of milk production in the European Union shows that the size of farms in Central and Eastern Europe is not optimal and that there are problems in the adoption of innovations and structural changes (Cechura, et al., 2016). It can be said that such a conclusion could also be relevant for Serbia. For the Western Balkans countries which are on the road to European Union membership, agriculture, and especially trade in agricultural products, is an important economic activity. The importance of this activity is also highlighted by the CEFTA agreement. Compared to other Western Balkan countries, Serbia is the only country that does not have a deficit in foreign trade in agricultural products (Natos et al. 2014). The price elasticity of demand is based on two basic elements: the prices and quantities demanded. Therefore, it expresses the intensity of responsiveness of demand of some goods to change in the price of those goods (Momirović, 2007). In quantitative terms, this relation is calculated as the quantity demanded of a product and percentage change in price. In relation to the intensity of the reaction of the quanity demanded of a product to a change in the price, elasticity can take several forms: perfectly inelastic demand $(=0)$, inelastic demand $(<1)$, unit elastic demand $(=1)$, elastic demand $(>1)$ and perfectly elastic demand $(=\infty)$, (Mankiw, 2004).

The price elasticity of demand implies ceteris paribus of other factors of demand. In other factors which influence the demand, but which have no price character, we include the following (Veselinovic, 2010):

- the amount of income of consumers (higher income-lower elasticity and vice versa);

- consumer habits (more pronounced habits-lower elasticity);

- the existence of substitute of the given product makes the demand more elastic, while lower elasticity is present with complementary goods;

- greater opportunities for the use of products for multiple purposes also means greater 
elasticity of demand, and vice versa;

- $\quad$ the elasticity of demand essentially depends on the products in the structure of demand, as well as on the needs it meets.

The quantity demanded of a product, as noted, does not always depend on the price, but also on other factors. The indifferent relation of demand towards the prices is shown in the situations where the elasticity of demand is not dependent on the price. In the short term, products can be complementary, but substitution shows growth in the long run (Chavas, 2016). In our work, we showed such situations in the analysis of price elasticity of demand of various types of agricultural products. Based on their characteristics, agricultural products represent a necessary condition for life. Therefore, people buy them regardless of the price, which makes the demand for these products to a lesser extent sensitive to changes in price. This is one of the main reasons which make the market of agricultural products mostly inelastic. Food prices may be the causes of social disorders (Bellemare, 2014). Developing countries are more volatile than developed. One of the key causes of their volatility are the price of goods (Jacks, et al., 2011). It is certain that the prices of agricultural products have a strong influence on stability. The research of 25 individual crop and livestock output supplies and 6 input demands in the US showed that the own-price input demand elasticities were also generally inelastic in each State of America (Villesca and Shumway, 1992). While analysing the price elasticity of demand, through review of 160 relevant studies, (Andreyeva et al., 2010) came up with the data showing that the coefficient of elasticity of fruit, poultry, milk, vegetables and eggs is less than zero $(<0)$. In addition to the prices having no significant impact on the elasticity of this market, the presence and influence of other factors that affect the elasticity of demand reinforce the inelasticity of this market. With the strong influence of non-price factors, the following phenomenon is observed: the quantities demanded of agricultural products do not decrease under the influence of an increase in the price, but instead they are of reverse movement, i.e. the quantity demanded of products increases. Here we cannot talk about Giffen's Paradox, since agricultural products do not belong to the group of inferior goods. To a lesser extent, we can see the occurrence of the decrease in the quantity demanded in parallel with the drop in price. This phenomenon also cannot be evaluated as Veblen effect, given that agricultural products cannot be classified as luxury goods. In any case, the indifference of elasticity of demand to price changes reinforces the effect of inelasticity of agricultural markets. The aim of this research is to arrive at a conclusion on the degree of elasticity of agricultural markets in Serbia, through the research of changes of the quantity demanded of products under the influence of changes in the price per unit of a product. The coefficients of elasticity obtained through calculation on the basis of statistical data on agricultural products (quantity, income from sale etc.) in Serbia, suggest that the market of agricultural products is largely inelastic. This market cannot, of course, be completely inelastic in all categories of agricultural products which are the subject of the analysis, just as it was demonstrated by the calculation of coefficients of elasticity. Agricultural products are sold in two market segments: the markets and in shops. At first glance, one might say that these two segments are, in a way, correlated, bearing in mind that this is a group of food products for which there is a latently growing demand, and taking into account the steady growth of per capita income, 
as well as the steady growth of the population. In accordance with these developments, the demand is growing. By applying the appropriate mathematical and statistical method, we found that these two segments of the market are completely independent.

\section{Methodology}

The main goal of this work is the study of elasticity of the most important economic indicators: price, demand and income of agricultural products on the territory of the Republic of Serbia. Based on the kind of these products, they are classified into following six different categories:
A. Fruit and grapes;
B. Vegetables;
C. Chiken and eggs: $\mathrm{C}_{1}$. Chicken and $\mathrm{C}_{2}$. Eggs;
D. Milk and milk products: $\mathrm{D}_{1}$. Milk and $\mathrm{D}_{2}$. Milk products.

In addition, based on the types of sales points, all the aforementioned categories of agricultural products were divided into two sub-categories (sectors):

1. The sale and purchase of agricultural products-Sector A (SA-abbreviation of the authors);

2. The sale of agricultural products on farmers' markets-Sector B (SB-abbreviation of the authors).

In this study, using some of the well-known facts about mathematical modeling of economic variables (see, for instance: Henderson, Quandt, 1971; Render, Stair, 1993; Božinović, Stojanović, 2006), the following two mathematical- quantitative methods were used:

1. In the first part of our analysis, we calculated the significance of the elasticity of the aforementioted economic indicators (variables), for all four afore-mentioned categories of agricultural products, SA and SB series, in particular. In economic theory, elasticity is the ability of certain economic variable $(y)$ to react with more or less intensity to changes in other economic variables $(x)$, which is in interdependence with $y$. An economic variable is more elastic if its reaction to changes in another variable is higher. The elasticity between economic variables $y$ and $x$ can be defined in two ways: in a functional form, or by the previously mentioned set of empirical values. As it was previously stated, one of the goals of this work is the investigation of functional dependence of economic variables, i.e. between the price and demand of agricultural products. Therefore, the elasticity of these economic indicators will be used. The elasticity (of $y$ with respect to $x$ ) is expressed by the so-called coefficient of elasticity, given by equality:

$$
E_{y, x_{0}}=\lim _{\Delta x_{0} \rightarrow 0} \frac{\frac{\Delta y_{0}}{y_{0}}}{\frac{\Delta x_{0}}{x_{0}}}=\frac{x_{0}}{y_{0}} \lim _{\Delta x_{0} \rightarrow 0} \frac{\Delta y_{0}}{\Delta x_{0}},
$$

where $x_{0}, y_{0}$ denote the realized values of the variables $x, y$, and $\Delta x_{0}, \Delta y_{0}$ are their 
changes per units, respectively. In this way, the coefficient of elasticity $E_{x, y}$ has represents the measure of degree of change $y$ with respect on $x$, and it has the following economic interpretation:

If the value of this coefficient is equal $E_{x, y}=k$, then increasing economic variable $x$ of $1 \%$ implies:

- If $k>0$, the variable $y$ increasing of $k \%$;

- If $k<0$, the variable $y$ decreasing of $k \%$.

Using this interpretation, in the following the detailed analysis of the elasticity of the income in relation on demand and price of all of the above categories of agricultural products will be given. For this purpose, we use the following interpretation of $E_{y, x}$, i.e. its absolute value $\left|E_{y, x}\right|$ :

- If $\left|E_{y, x}\right|>1$, the variable $y$ is elastic with respect to $x$;

- If $\left|E_{y, x}\right|<1$, the variable $y$ is inelastic with respect to $x$;

- If $\left|E_{y, x}\right|=0$, the variable $y$ is perfectly inelastic with respect to $x$;

- If $\left|E_{y, x}\right|=1$, the variable $y$ is indifferently elastic with respect to $x$;

- If $\left|E_{y, x}\right|=\infty$, the variable $y$ is perfectly elastic with respect to $x$.

2. In the second part, the correlation between elasticity of the SA and SB series is investigated. As it is known, correlation is a quantitative measure of dependence between two (agricultural) categories. If these categorias are labeled as $x, y$, correlation is usually expressed by the so-called Pearson's product moment correlation coefficients $(r)$ :

$$
r=\frac{n \sum x y-\sum x \sum y}{\sqrt{n \sum x^{2}-\left(\sum x\right)^{2}} \sqrt{n \sum y^{2}-\left(\sum y\right)^{2}}} .
$$

In dependence of the direction and the strength of correlation between $x$ and $y$, correlation coefficient $r$ takes values between -1 and 1 . In the case when $r>0$, the correlation is direct, while for $r<0$ there is an inverse correlation. In practice, the strength and degree of correlation, in dependence of absolute value $|r|$ is interpreted in the following way:

- $\quad 0.0-0.7$ : Weak correlation;

- $0.7-0.8$ : Emphasized correlation;

- $0.8-0.9$ : High correlation;

- $0.9-1.0$ : Very high correlation. 


\section{Results and discussion}

In this section, we consider the dependence between the prices and demand quantities of income of the aforementioned categories of agricultural products, additionally stratified according to the point of sales. The values of all of these indicatros, observed as data series in the period 2009-2015, are shown in the following Tables 1-2.

Table 1. Prices per units of different categories of agricultural products in shops and markets (in RSD).

\begin{tabular}{|l|l|l|l|l|l|l|l|l|}
\hline Product & Sector & 2009 & 2010 & 2011 & 2012 & 2013 & 2014 & 2015 \\
\hline \multirow{2}{*}{$\begin{array}{l}\text { A. Fruit and } \\
\text { grapes }\end{array}$} & SA & 40.20 & 54.59 & 47.34 & 68.40 & 55.57 & 59.49 & 80.85 \\
\cline { 2 - 9 } & SB & 95.73 & 98.51 & 114.61 & 129.65 & 141.01 & 138.63 & 154.82 \\
\hline \multirow{3}{*}{. Vegetables } & SA & 17.10 & 20.05 & 18.45 & 22.72 & 23.21 & 27.28 & 27.68 \\
\cline { 2 - 9 } & SB & 50.62 & 64.40 & 62.18 & 69.29 & 76.46 & 78.78 & 78.32 \\
\hline \multirow{2}{*}{. Poultry } & SA & 90.27 & 88.85 & 105.75 & 114.53 & 139.47 & 120.17 & 112.90 \\
\cline { 2 - 9 } & SB & 228.06 & 218.52 & 247.06 & 289.39 & 311.59 & 314.97 & 291.67 \\
\hline \multirow{2}{*}{. Eggs ${ }^{* *}$} & SA & 6.76 & 5.66 & 6.91 & 8.36 & 7.94 & 8.24 & 7.79 \\
\cline { 2 - 9 } & SB & 10.08 & 9.07 & 10.54 & 12.68 & 11.91 & 11.81 & 12.37 \\
\hline \multirow{2}{*}{$\mathrm{D}_{1} \cdot$ Milk ${ }^{* * *}$} & SA & 21.65 & 23.33 & 28.56 & 30.34 & 32.84 & 32.62 & 31.66 \\
\hline \multirow{2}{*}{$\mathrm{D}_{2}$. Milk products } & SB & 44.47 & 50.32 & 55.91 & 58.15 & 65.54 & 64.85 & 62.91 \\
\cline { 2 - 9 } & SA & 199.23 & 206.45 & 194.94 & 85.71 & 250.00 & 291.67 & 315.22 \\
\hline
\end{tabular}

Note: ${ }^{*}$ Price is expressed per kilogram; ${ }^{* *}$ Price is expressed per unit; ${ }^{* * *}$ Price is expressed per liter. Source: Statistical Office of the Republic of Serbia-Statistical Yearbook of Serbia, 2010-2016.

The analysis of frequency of price changes shows an upward tendency in the product category $\mathrm{A}$ in the SA. In relation to the frequency of price changes of other categories of agricultural products in the SA, this tendency shows the most pronounced fluctuations observed from year to year. The lowest frequency is shown by the analysed prices of agricultural product categories B and D1, without any abrupt changes in certain years. This phenomenon of sudden price fluctuations is mostly pronounced in the categories $\mathrm{C} 1, \mathrm{C} 2$ and D2. The category $\mathrm{C} 1$ reached its minimum price in 2010. After this year, the increase in prices is pronounced, as they reached their maximum in 2013; in 2014 and 2015, there was a decline in prices. Almost identical changes are shown in the category $\mathrm{C} 2$ prices, reaching the minimum price in the year 2010 and the maximum price in 2012. After this year, the prices were stable (minimally variable), all the way until 2015, when the minimum fall of these prices occurred. The frequency of price changes of category D2 prices shows "the sharpest" turnaround. In the period 2010-2012, there was a significant drop in prices, while in 2012, the minimum was reached. After this year, a significant price increase began, reaching the maximum in 2015.

The frequency of price changes of agricultural products in the SB, demonstrates the tendency of stable growth without any major fluctuations (sudden fall and increase of prices). The exception to this rule is the frequency of price changes with the rapid changes in the product category C2. The price minimum of this agricultural product was reached in 2010. After this 
year, the price increase began, reaching the maximum in 2012. In 2013 and 2014 the prices were stable, but in 2015 the prices were rising.

The prices of agricultural products in SB were significantly higher than the prices of agricultural products in the SA throughout the analysed period. This ratio of prices also had a significant impact on the amount of agricultural products sold in shops and markets (see Table 2). The comparison of the frequencies of price changes of agricultural products in SA and SB, indicates a harmonious relation. Such (harmonious) relation is observed in approximately the same time and the same price changes throughout the observation period. The prices of products from the category B from both sectors have approximately the same changes in the analysed period, reaching the maximum in 2015. In the category $\mathrm{C} 1$ and $\mathrm{D} 1$, the prices in both sectors were rising until 2013-2014, and in 2015 a decline of the prices of these products was recorded. To a certain extent, the prices in the category A show a disharmonic frequency. In this position, the SB prices have a stable growth without significant fluctuations, while the SA prices, in contrast, have frequent fluctuations per year of the period analysed. The situation is similar when it comes to the product category D2. In this position, starting from 2010, the SB prices have had a stable growth, while the SA prices, starting from 2010, show a decline and after this year, a significant and rapid growth. It is interesting that perhaps the highest level of harmony was achieved in the frequency of price changes of the category $\mathrm{C} 2$, which is characterized by frequent price fluctuations in both sectors. The prices in this category of agricultural products had almost identical changes (decline and growth) per year of the analysed period, except in the year 2015, in which the growth of prices in the SB and a fall in the SA prices was realized.

Table 2. The quantity demand of the different categories of agricultural products in shops and markets (per tones and litres)

\begin{tabular}{|l|l|l|l|l|l|l|l|l|}
\hline Product & Sector & 2009 & 2010 & 2011 & 2012 & 2013 & 2014 & 2015 \\
\hline \multirow{2}{*}{$\begin{array}{l}\text { A. Fruit and } \\
\text { grapes }\end{array}$} & SA & 150,262 & 145,900 & 170,368 & 133,638 & 198,246 & 188,172 & 251,621 \\
\cline { 2 - 9 } & SB & 50,932 & 48,238 & 47,169 & 43,933 & 42,968 & 44,781 & 48,883 \\
\hline \multirow{3}{*}{. Vegetables } & SA & 108,624 & 102,286 & 157,845 & 107,907 & 142,280 & 163,183 & 200,459 \\
\cline { 2 - 9 } & SB & 126,408 & 118,657 & 125,211 & 120,860 & 130,729 & 130,135 & 137,766 \\
\hline \multirow{2}{*}{. Poultry* } & SA & 19,752 & 17,467 & 14,657 & 6,531 & 18,140 & 16,860 & 31,283 \\
\cline { 2 - 9 } & SB & 6,472 & 6,155 & 6,375 & 6,061 & 6,239 & 6,372 & 6,209 \\
\hline \multirow{2}{*}{. Eggs** } & SA & 41,259 & 62,869 & 131,578 & 149,801 & 287,319 & 285,984 & 368,454 \\
\cline { 2 - 9 } & SB & 203,375 & 203,412 & 214,858 & 195,477 & 208,567 & 213,227 & 235,638 \\
\hline \multirow{2}{*}{$\mathrm{D}_{1} \cdot$ Milk*** } & SA & 723,000 & 686,000 & 681,000 & 712,000 & 746,000 & 794,000 & 837,000 \\
\hline & SB & 832 & 775 & 769 & 705 & 595 & 586 & 604 \\
\hline \multirow{2}{*}{$\mathrm{D}_{2}$. Milk products } & SA & 261 & 155 & 277 & 175 & 104 & 72 & 92 \\
\cline { 2 - 8 } & SB & 12,913 & 13,986 & 13,875 & 13,850 & 13,863 & 14,725 & 14,081 \\
\hline
\end{tabular}

Note: Note: * Expressed in thousands of pieces; ${ }^{* *}$ Expressed in thousands of liters; ${ }^{* * *}$ Only domestic processing without industry.

Source: Statistical Office of the Republic of Serbia - Statistical Yearbook of Serbia, 2010-2016. 
The frequency of changes in the quantity demanded of products in the SA and SB is significantly different. In the categories of agricultural products in the SA, the frequency of changes in the quantity demanded per year of the analysed period is intense, i.e. the quantities of the products sold in this sector vary from year to year. This is a characteristic of the product category A; in this product category, quantities are significantly changed in each year of the analysed period, in such a way that they are alternately falling and increasing every year, starting from the first year of the analysed period (2009). In the product category B, these quantity changes show a sudden, sharp rise in 2011, followed by a sudden drop in 2012; after this year, up to 2015, a very intense and pronounced growth is present. In the product category $\mathrm{C} 1$, the quantity changes reach a breaking point in the year 2012, that is, a sharp drop from 19,752 tons in 2009 to only 6,531 ton in 2012. After the year 2012, a sudden and very intense quantity increase is shown - of about five times in the year 2015. In the product category $\mathrm{C} 2$, there is a strong continuous quantity increase, from 41,259 thousand of pieces in 2009 to 368,454 thousand of pieces in 2015, which is a quantity of about nine times. The deviation from such variable frequency of changes in quantity is shown in the product category D1 and D2, where changes in the quantities are significantly fewer.

The frequency of changes in quantity per category of agricultural products in the SB, shows significantly smaller annual fluctuations in relation to the quantities of products in the SA. The analysis of market dominance indicates that product category A in the SA is more dominant in comparison to category A in the SB throughout the period analysed. Within the category $\mathrm{B}$, it is shown that the category $\mathrm{B}$ in the SA is more dominant in comparison to the category B in the SB only starting from the year 2013, when the market was practically taken over. In the category $\mathrm{C}$, it can be seen that the category $\mathrm{C} 1$ in the $\mathrm{SA}$ is more dominant on the market in comparison to the category $\mathrm{C} 1$ in the $\mathrm{SB}$. Identical situation is also evident in the category $\mathrm{C} 2$, where it is shown that the category $\mathrm{C} 2$ in the SA begins to dominate and take the market over from the category C2 in SB in the year 2013. The category D includes the distribution of the market, so the category D1 in SA dominates the market throughout the period analysed, while the category D2 in SB is also dominant in the market throughout the period analysed.

The coefficients of price elasticity of demand are given in the following Table 3 and, in addition, shown in Figure 1.

Table 3. The coefficients of price elasticity of demand of the agricultural products in shops and market.

\begin{tabular}{|l|l|l|l|l|l|l|l|}
\hline Product & Sector & 2010 & 2011 & 2012 & 2013 & 2014 & 2015 \\
\hline \multirow{2}{*}{$\begin{array}{l}\text { A. Fruit and } \\
\text { grapes }\end{array}$} & SA & -0.0811 & -1.2628 & -0.4846 & -2.5774 & -0.7204 & 0.9391 \\
\cline { 2 - 8 } & SB & -1.8214 & -0.1356 & -0.5228 & -0.2507 & -2.4999 & 0.7844 \\
\hline \multirow{3}{*}{ B. Vegetables } & SA & -0.3382 & -6.8066 & -1.3670 & 14.7700 & 0.8378 & 15.5790 \\
\cline { 2 - 8 } & SB & -0.2252 & -1.6023 & -0.3039 & 0.7891 & -0.1497 & -10.0426 \\
\hline \multirow{2}{*}{ C. Poultry } & SA & 7.3541 & -0.8458 & -6.6776 & 8.1628 & 0.5099 & -14.1403 \\
\cline { 2 - 7 } & SB & 0.4240 & 0.2737 & -0.2875 & 0.3828 & 1.9652 & 0.3458 \\
\hline
\end{tabular}




\begin{tabular}{|l|l|l|l|l|l|l|l|}
\hline \multirow{2}{*}{$\mathrm{C}_{2} \cdot$ Eggs $^{*}$} & SA & -3.2188 & 4.9486 & 0.6600 & -18.2727 & -0.1230 & -5.2804 \\
\cline { 2 - 8 } & SB & -0.0018 & 0.3472 & -0.4443 & -1.1027 & -2.6610 & 2.2166 \\
\hline \multirow{2}{*}{$\mathrm{D}_{1}$. Milk } & SA & -0.6595 & -0.0325 & 0.7304 & 0.5795 & -9.6047 & -1.8402 \\
\cline { 2 - 8 } & SB & -0.5208 & -0.0697 & -2.0773 & -1.2277 & 1.4368 & -1.0268 \\
\hline $\begin{array}{l}\mathrm{D}_{2} \cdot \text { Milk } \\
\text { products }\end{array}$ & SA & -11.2068 & -14.1178 & 7.7771 & -1.1720 & -1.8460 & 3.4403 \\
\cline { 2 - 8 } & SB & 15.9859 & -0.0771 & -0.0197 & 0.0102 & 4.3671 & -1.2222 \\
\hline
\end{tabular}

Source: Computation in Excel: Vukadinović, Damnjanović, 2017.

The price elasticity of demand is determined by the quotient of two determinants that are expressed by means of percentage changes. These determinants are the percentage change in the quantity demanded of a product and the percentage change in price. The price elasticity exists if price changes have an impact on the changes in the quantity demanded of a product. The price increase affects the reduction of the quantity demanded of a product, while price reduction affects the growth of the quantity demanded of a product. Based on the extent to which the changes in the quantity demanded of a product are sensitive to price changes, two types of demand can be differentiated: elastic and inelastic. The measure for determining these elasticity categories is the coefficient 1 (one). Overall, the price elasticity of demand exists if price changes and changes in the quantity demanded of a product are moving in the opposite direction. In addition to these two situations, in which the quantity demanded of a product responds to changes in price, there are situations in which the quantity demanded of a product does not respond to price changes. These are the situations in which a certain quantity demanded of a product is indifferent to the price impact. Such are the situations when the price changes and changes in the quantity demanded of a product go in the same direction. Price reduction follows the reduction of the quantity demanded of a product, and vice versa - an increase in cost follows the increase in the quantity demanded of a product. For these situations, it is clear that the quantity demanded is not affected by the prices, but other factors of impact on demand, and therefore we can say that the price elasticity of supply in these situations is indifferent to the impact of price changes. In Table 4, the coefficients are shown by using a minus sign (-). The positions where these signs are marked, show the presence of elastic or inelastic demand. The coefficients that are shown in the table without the minus sign (-) indicate the existence of an indifference of the price elasticity of demand at the positions where they are displayed.

The analysis of the coefficients of elasticity of demand shows that the elasticity of demand is more dominant in comparison to the inelasticity. However, if one takes into account the indifference of the elasticity of demand, then the situation changes and it becomes evident that the elasticity of demand does not dominate the market of the displayed categories of agricultural products. The largest number of indifferent positions, if categories of agricultural products are observed individually, is found in the category $\mathrm{C} 1$. This situation reflects the fact that in this category there is the largest number of positions in which demand is not dependent on changes in prices and that the indifference is apparently affected by other factors of demand that are of non-price character. The highest elasticity coefficient was calculated in the category C2 in the SA and it is -18.2727 , which means that in $2013,1 \%$ of changes in prices 
sparked 18:27 \% of changes in the quantity demanded of agricultural products. The minimum coefficient of elasticity was calculated in category D1 in the SB and it is -1.0268, which means that in $2013,1 \%$ of price changes caused $1.03 \%$ of changes in the quantity demanded of products. This coefficient almost brings closer the elasticity of demand to unit elasticity. The highest coefficient of inelasticity was calculated in the category $\mathrm{C} 1$ in the SA and it is -0.8458 , which means that the price change of $1 \%$ in 2011 caused a change in the quantity demanded of products by $0.85 \%$. The lowest coefficient of inelasticity was calculated in the category $\mathrm{C} 2$ in the SB and is -0.0018 , which means that $1 \%$ of change in prices in this category caused only $0.0018 \%$ of the change of product quantities. This coefficient brings closer the elasticity of demand in this category to the perfectly inelastic demand. The degree of indifference of elasticity of demand to price changes is most pronounced in the category D2 in the SB and amounts to 15.9859. This coefficient indicates that in 2010, regardless of the price increase of $0.52 \%$, the product quantity increased by $8.3 \%$ (based on the data in Table 1 and 2 ). The smallest difference is expressed by the coefficient 0.01 in the category D2 in the SB. The frequency of the elasticity coefficients and elasticity indifference is shown in Figure 1.

Figure 1. The coefficients of price elasticity demand of the agricultural products in shops and market
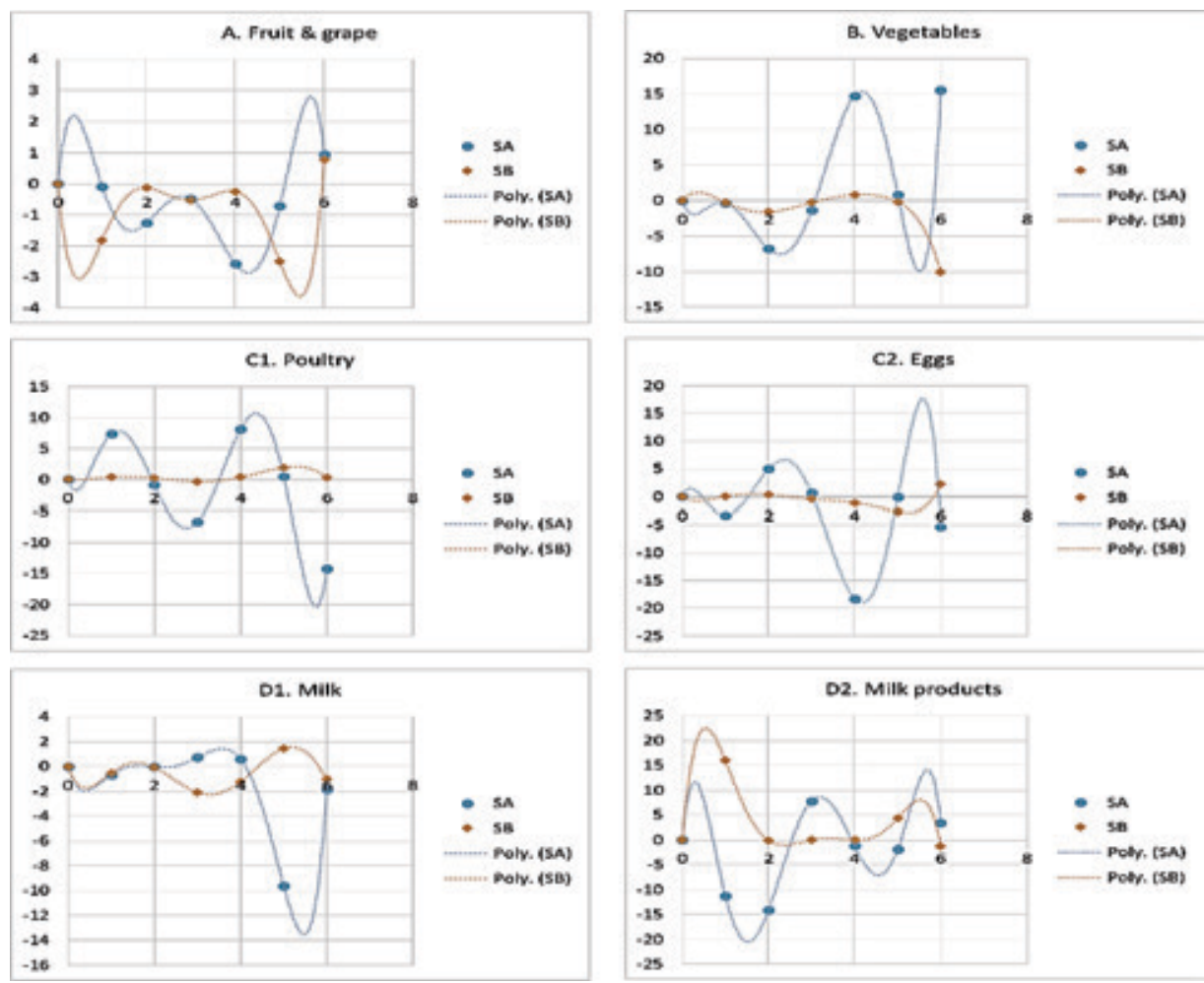

Source: Computation in Excel: Vukadinović, Damnjanović, 2017. 
The fluctuation of the coefficients of price elasticity of demand in the category A in the SA, indicates that demand in this category of agricultural products has a pronounced alternating frequency of changes of elasticity and inelasticity. This situation points to the frequent occurrence of alternating falls and growth of prices in each year of the analysed period. The demand in the category A in the SB shows different characteristics. The continuity of price growth with a decrease in the quantity demanded of a product, without alternating annual fluctuations (fall-growth), had an impact on the fact in such a way that demand in this product category is largely inelastic. The indifference elasticity of demand was demonstrated only in 2015 , in both sectors, in which the quantity demanded of a product increased regardless of the price increase.

The elasticity of demand in the category B of agricultural products shows two completely different situations in relation to the SA and SB. In the product category B in the SA, a large time span of indifference of demand is shown, which is spread over three years 2013-2015. In these years, there has been an increase in the quantity demanded of products regardless of the price increase. The inelasticity of demand is expressed only in 2010, while the elasticity of demand with a high range of values of the coefficient of elasticity is expressed in 2011-2012. In this category, indifference is dominant in comparison to the coefficients of elasticity and inelasticity. In the category B in the SB, the indifference appears only in the year 2013. With the increase in the price, there was an increase in quantity demanded of products. In three years of the analysed period, the demand is inelastic, while the demand is elastic two years, especially in 2015. This product category is dominated by inelastic demand.

The demand for the product category $\mathrm{C}$ in both sectors shows the dominance of the indifference of demand in relation to price changes. In the category $\mathrm{C} 1$, indifference was demonstrated in three years of the analysed period: in 2010 and in 2013-2014. The prices of products in 2010 and 2014 dropped, and the quantity demanded of products also increased, while in 2013 the situation was reversed. The prices were increased, as well as the quantity demanded of products. Demand is elastic in 2012 and 2015, while it is inelastic in the year 2011. This product category is dominated by indifference of demand. The elasticity of demand in the category $\mathrm{C} 1$ in the SB exists only in 2012. In that year, demand is elastic. In all other years, indifference is absolutely dominant. This category also contains the greatest indifference in relation to other categories of products analysed.

The indifference of demand in the category C2 in SA was demonstrated in two years of the analysed period in which the price increases was followed by the increase in quantity demanded of products. In three years, the elastic demand was dominating, and in 2013, the highest coefficient of elasticity was reached, when compared to all other categories of products analysed. Demand was inelastic only in 2014. In the sector SB, demand for the product category $\mathrm{C} 2$ is evenly distributed, in such a way that elastic demand is demonstrated in two years (in 2013 and 2014), while demand is inelastic also in two years (in 2010 and 2012). An interesting situation is seen in 2010, in which the inelasticity of demand, according to the coefficient value, is almost equalized with a perfectly inelastic demand. Indifference of demand was demonstrated in 2011 and 2015. 
The demand in the category D1 in the SA shows an identical distribution of the coefficient of elasticity according to the structure, as well as in the category C2 in the SB. In two years, the demand is demonstrated to be inelastic (in 2010 and 2011), while over the next two years, indifference of demand is demonstrated (2012 and 2013); in the next two years elastic demand is demonstrated (2014 and 2015). In the sector SB, the product category D1, dominates elastic demand which appears in three years of the analysed period 2012-2013 and 2015. Inelastic demand is present in 2010 and 2011, and indifference is demonstrated in 2014.

In the category D2 in the SA, elastic demand that is demonstrated in four years of the analysed period is dominant, while indifference of demand is demonstrated in two years. In the sector $\mathrm{SB}$ indifference is dominant in three years, inelastic demand is seen in two years, while demand is elastic in one year of the analysed period.

\section{Conclusion}

The price elasticity of demand is analysed from the standpoint of basic parameters that affect this indicator. The analysis of price movements of the covered categories of agricultural products, on a general level, shows that the prices of agricultural products in the SB are consistently higher throughout the period analysed and compared to all the analysed categories of products in the SA. On a general level of the analysis in both sectors (the SA and SB), regardless of occasional fluctuations, the prices show a constant upward trend. Within the sector, it is demonstrated that the fluctuation of prices in the SB is lower than in the SA, i.e. the prices in the SB show a more stable a tendency of growth than the prices in the SA. By comparing the changes in prices in both sectors, it can be concluded that there is a harmony of changes. In the periods of price growth in the SA, the price growth is also shown in the SB. The same phenomenon is observed in the reverse direction. The exception to this rule is the product category A.

The frequency of changes in the quantity demanded of products is different in the comparison of the SA and SB. It was demonstrated that the fluctuation of demanded products was more significant in the SA than in the SB. This phenomenon corresponds to the constant price changes in the SA, while a more stable movement of the quantity demanded in the SB is in correspondence with lower price fluctuations in the SB. The analysis of the domination of the market of agricultural products showed that throughout the period analysed, the products of the category D1, A and C1 from the SA, dominate the market, in relation to the same product category in the SB. In the SB sector, the category D2 demonstrates market dominance, while a change of dominance occurred in product categories B and $\mathrm{C} 2$. The product category $\mathrm{B}$ in the SA assumes dominance in relation to B in the SB in 2013, while the category C2 in the SA assumes dominance in relation to C2 in SB also in 2013. After the year 2013, the SA completely dominates the market of agricultural products.

The analysis of the structure of the coefficient of price elasticity of demand shows a high heterogeneity. Such character of the structure of the coefficient of price elasticity lies in the fact that none of the product categories in both sectors has a homogeneous structure in terms of representation of elastic or inelastic demand only. The coefficients representing the elasticity 
of demand are represented in the structure of $34.72 \%$ of coefficients; the coefficients which exhibit lack of elasticity account for $29.17 \%$, while the coefficients that indicate indifference of demand account for $36.11 \%$. The analysis of the distribution of dominance of certain types of elasticity and indifference, showed that inelastic demand dominates the market of products from the category A in the SA and SB, and B in the SB. Elastic demand is dominant in product category $\mathrm{C} 2$ in the SA, D1 in the SB and D2 in the SA. The indifference of elasticity of demand is dominant in the product category B in SA, C1 in the SA and SB, and D2 in the $\mathrm{SB}$. The uniform distribution of elasticity is shown in the product category $\mathrm{C} 2$ in the $\mathrm{SB}$ and D1 in the SA. Taking into account the distribution of the coefficients of both types of the price elasticity of demand and indifference, as an analysis of the distribution of the domination of different types of the price elasticity of demand, it can be concluded that the market of agricultural products in Serbia is largely inelastic. Overall, 34.72\% of demand in the market of agricultural products in Serbia reacts to price changes, while $65.28 \%$ of the market has little or zero response to price changes.

The analysis of the correlation of the price elasticity of demand between the analysed categories of agricultural products shows that the correlation does not exist, except in the three exceptions. Such a distribution of correlation coefficients showed that these are two independent markets, without mutual influence in terms of price elasticity of demand.

\section{Literature}

1. Andreyeva, T., Long, M. W., Brownell, K. D. (2010). The Impact of Food Prices on Consumption: A Systematic Review of Research on the Price Elasticity of Demand for Food. American Journal of Public Health, vol. 100, no. 2, pp. 216-222

2. Anderson, P. L., McLellan, R. D., Overton, J. P., Wolfram, G. L. (1997). Price elasticity of demand. MacKinac Center for Public Policy. Accessed October, 13, 2010. Available at: https://www.mackinac.org/1247

3. Bellemare, M. F. (2014). Rising food prices, food price volatility, and social unrest, American Journal of Agricultural Economics, Vol. 97, No. 1, pp. 1-21.

4. Božinović, M.; Stojanović, V. (2006) Mathematical methods and models in economy of enterprises (in Serbian). High School of Economy, Leposavić.

5. Božinović, M.; Stojanović, V. (2011) Mathematical models of monopolistic competition: theoretical principles and applications. Facta Universitatis, Series: Economics and Organization, Vol. 8, No. 2, pp. 121 - 129.

6. Cechura, L., Grau, A., Hockmann, H., Levkovych, I., Kroupova, Z. (2016). Catching Up or Falling Behind in European Agriculture: The Case of Milk Producti,. Journal of Agricultural Economics. Vol. 68, No. 1, pp. 206-227.

7. Chavas, J. P. (2016). On the dynamics of food demand: a benefit function approach, European Review of Agricultural Economics, Vol. 43, No. 3, pp. 401-43.

8. Ghosh, J. (2010). The unnatural coupling: Food and global finance. Journal of 
Agrarian Change, Vol. 10, No. 1, pp. 72-86.

9. Gilbert, C. L. (2010). How to understand high food prices, Journal of Agricultural Economics, Vol. 61, No. 2, pp. 398-425.

10. Guerrero, S., Hernández-del-Valle, G., Juárez-Torres, M. (2016). Using a functional approach to test trending volatility in the price of Mexican and international agricultural products, Agricultural Economics, Vol. 48, No. 1, pp. 3-13.

11. Henderson, J.M.; Quandt, R.E. (1971) Microeconomic theory: a mathematical approach. 2nd ed., McGraw-Hill, New York.

12. Jacks, D. S., O'Rourke, K. H., Williamson, J. G. (2011). Commodity price volatility and world market integration since 1700, Review of Economics and Statistics, Vol. 93, No. 3, 800-813.

13. Mankiw, N.G. (2004). Principles of Economics, 3rd Edition. London: Harcourt College Publishers, (Izdanje Ekonomskog fakulteta u Beogradu 2006. godine na srpskom jeziku ISBN: 86-403-0754-7.).

14. Momirović, D. (2007). Elastičnosti tražnje poljoprivrednih proizvoda. Ekonomika poljoprivrede, vol. 53, no. 5-6, pp. 49-55, Institut za ekonomiku poljoprivrede, Beograd, Srbija.

15. Natos, D., Staboulis, C., Tsakiridou, E. (2014). Agricultural Trade Integration in Western Balkans: Orientation and Complementarity, Agricultural Economics Review, Vol. 15, No. 2, pp. 85-99.

16. Nazzaro, C., Marotta, G. (2016). The Common Agricultural Policy 2014-2020: scenarios for the European agricultural and rural systems, Agricultural and Food Economics, Vol. 4, No. 1, pp.16-20.

17. Petković, D. (2008) The impact of market structure on economic efficiency - an empirical analysis of Markets milk in Serbia (in Serbian). Serbian economic forum, Working document.

18. Render, B.; Stair, R. (1993) Quantitative analysis for management. Allyn and Bacon, London, UK.

19. Villezca Becerra, P. A., Richard Shumway, C. (1992). State-level output supply and input demand elasticities for agricultural commodities, The Journal of Agricultural Economics Research, Vol. 44, No. 1, pp. 22-34.

20. Veselinović, P., (2010). Ekonomija (ISBN: 978-86-7912-277-3), Univerzitet Singidunum, Beograd 
ANALIZA INDIFERENCIJE I CENOVNE ELASTIČNOSTI TRAŽNJE RAZLIČITIH KATEGORIJA POLJOPRIVREDNIH PROIZVODA

\title{
Predrag Vukadinović, Aleksandar Damnjanović5 ${ }^{5}$,Jelena Krstić-Ranđić ${ }^{6}$
}

\begin{abstract}
Apstrakt
Uovom raduje opisana analiza cenovne elastičnosti četiri različite kategorije poljoprivrednih proizvoda u Republici Srbiji. Razlikovanjem cena i tražnje za ovim proizvodima prema prodajnim mestima, kao i korišćenjem metode aproksimacije najmanjih kvadrata, elastičnost za svaku različitu poljoprivrednu kategoriju izražena je u funkcionalnom obliku. U skladu sa tim, koeficijenti elastičnosti cena i tražnje su izračunati i analizirani između različitih poljoprivrednih kategorijaja. Rezultatidokojih smodošlipokazujudaje tržištepoljoprivrednih proizvoda u Srbiji pretežno neelastičnojer dominiraju koeficijenti neelastičnosti i indiferencija tražnje na promene cena. Uticaj faktora na elastičnost tražnje koji nisu cenovnog karaktera se pokazao kao veoma izražen. Analiziran je i odnos dva segmenta tržišta poljoprivrednih proizvoda (pijace i marketi) i pokazano je da ova dva segmenta imaju neznatnu korelaciju.
\end{abstract}

Ključne reči: cenovna elastičnost tražnje, tražnja, cene, tražena količina, indiferencija

4 Vanredni profesor, dr Predrag Vukadinović, Univerzitet Singidunum, Danijelova Ulica br. 32, 11000 Beograd, Srbija, Telefon: +381 11309 3741, E-mail: pvukadinovic@singidunum.ac.rs.

5 Vanredni profesor, dr Aleksandar Damnjanović, Visoka škola akademskih studija „Dositej“, Trg Nikole Pašića no. 7, 11000 Belgrade, Srbija, Telefon: +381 640028388 , E-mail: adm.tfc@gmail.com.

6 Docent, dr Jelena Krstić Ranđić, Visoka poslovna strukovna škola Leskovac, Vlade Jovanovica 8, 16000 Leskovac, Srbija, Telefon: +381 6116424 75, E-mail: krstic.jelena@vpsle.edu.rs.

EP 2017 (64) 2 (671-685) 